\title{
Article \\ Impact of Induced Seismicity on the Housing Market: Evidence from Pohang
}

\author{
Jengei Hong ${ }^{1}{ }^{(\mathbb{C}}$, Hyunjae Jo $^{2}{ }^{(\mathbb{D}}$, Ducksu Seo $^{3,4, *(\mathbb{C})}$ and Songhee You ${ }^{3}$ \\ 1 Department of Management and Economics, Handong Global University, 558 Handong-ro, Buk-gu, \\ Pohang 37554, Korea; hwgh024@handong.edu \\ 2 Department of Industrial and Management Engineering, Pohang University of Science and Technology, \\ 77 Cheongam-ro, Nam-gu, Pohang 37673, Korea; present@postech.ac.kr \\ 3 Department of Spatial Environment System Engineering, Handong Global University, 558 Handong-ro, \\ Buk-gu, Pohang 37554, Korea; shyou@handong.edu \\ 4 Institute for Global Education, UNAI Korea, 325 Bongeunsa-ro, Gangnam-gu, Seoul 06103, Korea \\ * Correspondence: handonge@handong.edu; Tel.: +82-54-260-1432
}

check for updates

Citation: Hong, J.; Jo, H.; Seo, D.; You, S. Impact of Induced Seismicity on the Housing Market: Evidence from Pohang. Buildings 2022, 12, 286. https://doi.org/10.3390/ buildings 12030286

Academic Editors: Mats Wilhelmsson and Agnieszka Zalejska Jonsson

Received: 4 February 2022

Accepted: 25 February 2022

Published: 2 March 2022

Publisher's Note: MDPI stays neutral with regard to jurisdictional claims in published maps and institutional affiliations.

Copyright: (C) 2022 by the authors. Licensee MDPI, Basel, Switzerland. This article is an open access article distributed under the terms and conditions of the Creative Commons Attribution (CC BY) license (https:// creativecommons.org/licenses/by/ $4.0 /)$.

\begin{abstract}
In this study, we analyze the case of induced seismicity in Pohang, South Korea, in 2017 to investigate the effect of seismic risk perception on the local residential property market. Based on a hedonic pricing model with a difference-in-differences method, we examine the geographic distribution of the effects of unexpected earthquake hazards. Our results indicate an overall reduction in local property values, but the magnitudes of negative externality for housing prices decrease with respect to the distance from the epicenter. In areas within $3 \mathrm{~km}$ of the epicenter, the asset value reduced by approximately $20 \%$ after an earthquake event, but if the distance from the epicenter was higher than $12 \mathrm{~km}$, the negative effect on the price was not significant. In addition, we examine how the experience of seismic events affect the preference on the anti-seismic building structure. The results show that the market valuation on the anti-seismic system significantly escalated after the earthquake.
\end{abstract}

Keywords: induced seismicity; housing price; hedonic; difference-in-differences; Pohang

\section{Introduction}

An earthquake of magnitude 5.4 on the Richter scale occurred in Pohang, South Korea, on 15 November 2017. As well as being the second largest recorded earthquake in Korea, it was also the first induced seismicity caused by the excessive pressure of water injection underground for geothermal power generation [1,2]. In this study, we examine the effect of new perceived seismic risks on local housing values in the case of induced seismicity. Conducting a market assessment of seismic risks is a complex task because the expected disutility from seismic risk has already been indicated by determining earthquake-prone areas [3]. Individual perceptions about earthquakes are not an observable variable; thus, researchers have addressed the following issues in an effort to estimate the effect of seismic risk on housing values: ensuring that earthquake risks are properly reflected in advance, determining the information that affects people's perceptions about earthquakes [4], and the interactions between earthquake experiences and subjective assessment of earthquake risks [5].

Examining induced seismicity in Pohang provides an interesting case study to observe the effects of changes in the perceived seismic risk on the local housing market. Prior experiences of natural earthquakes have not been noted in Pohang city, and market participants had not anticipated an earthquake of this magnitude on 15 November 2017. In this study, we conducted an experiment to determine methods for the assessment of seismic risks in the housing market. We focus on the magnitude and features of housing devaluation caused by induced seismicity in Pohang. Our empirical model captures the effect of seismicity on 
housing value by using the difference-in-differences (DID) framework. Data is collected on 4201 apartment transactions in Pohang from 14 November 2016 to 16 November 2018 (i.e., one year preceding and following the earthquake on 15 November 2017) and differences in the effects of this seismic event based on distance from the epicenter are examined.

There are two main reasons for analyzing seismic effects based on the distance from the epicenter. First, an individual's subjective experience with earthquakes has a decisive effect on their perception of earthquake risk [5]. Residents living near the epicenter physically experience more vibration and, consequently, the market experiences devaluations due to earthquakes. These can be more severe in areas closer to the epicenter because residents living in these areas may react sensitively to changes in the environment. Second, by comparing the extent of housing devaluation with respect to the distance from the epicenter, the effects from other disturbances on local housing values could be controlled. Housing prices before and after an earthquake can also be affected by other factors, such as shortterm business cycles, interest rates, and local economic conditions. Therefore, discerning the effects of seismicity would be difficult if the model only determines changes in housing values before and after a seismic event. However, although economic factors can have similar effects on property values in the area, the intensity of the seismic effect may largely depend on the distance from the epicenter. This implies that comparing the changes based on the distance from the epicenter can enable us to observe the after-control effect of seismicity.

In addition, we analyze how changes in perceived seismic risk affect the preference for utilizing anti-seismic systems in housing. The value of an anti-seismic system depends on the expected loss from the occurrence of seismic events. For example, in an earthquakeprone area, market participants anticipate a high possibility of seismic events, thereby indicating that their expected loss from the occurrence of seismic events is also high. This implies that the willingness to pay for an anti-seismic system can vary among market participants based on their perception of seismic risks. Therefore, if induced seismicity leads to changes in perceived seismic risks, the market valuation of the anti-seismic system may also change. Based on this context, we examined whether the shadow price of the anti-seismic system increased after the Pohang earthquake.

This study contains five sections. Section 1 introduces research backgrounds, purposes, and frameworks. Section 2 includes a literature review with theoretical and empirical studies. Section 3 indicates research methods such as site selection, analytical model, data collection, and variable setting. Section 4 shows hedonic modeling results and interpretations for price determinant choices. Section 5 , the conclusion, summarizes the study as well as its implications, limitations, and further research directions.

\section{Literature Review}

\subsection{Theoretical Review of Hedonic Pricing Model}

The most frequently applied model in existing studies is the hedonic pricing model. The term "hedonic" was firstly used by Court [6] to examine demand and prices for personal sources of pleasure. He believed that commodities include various attributes to meet personal preferences and multivariate statistical methods could be applied in housing price studies. His argument was further developed by the consumer theory of Lancaster [7]. He highlighted the decision-making process of customers to purchase composite goods, which contain a variety of attributes. Rosen [8] then applied the discussion of hedonic theory to a pricing model. In the assumption of market competitiveness and separable utility, the value of a property is broken down into the value of its characteristics; this value is referred to as "shadow prices". He developed the theoretical foundation of a bid price $(\varphi)$, which indicates the maximum willingness to pay for a good. This had significant implications for advanced price regression models and was applied widely in housing market analysis and urban studies [9]. The hedonic pricing model in housing studies is based on the idea that the total price of a house consist of the values of multiple attributes of the residential property, and a customer has a willingness to pay for the package of 
the housing attributes. The hedonic regression methods have been further developed to examine more accurate price determinants such as the quantile regression model $[10,11]$, neural network hedonic model [12,13], and machine learning model [14]. These methods have recently attracted attention because they can circumvent the disadvantages of using the hedonic pricing model. Since it is known that the quantitative result of a hedonic model can be potentially distorted when there are submarkets, some machine learning models can accurately estimate house prices even with the existence of housing submarkets [14].

A typical hedonic house pricing model includes not only housing structural attributes but also locational attributes [15-17]. Housing structure indicates the physical characteristics and conditions of housing and land, such as residential building size and quality, room arrangement and quantity, house utilities, and parking [18-21]. The importance of housing structure attributes can change over time and fluctuates according to the cultures, traditions, and local climates of different countries. However, the attributes of room number and housing unit size are relatively significant in most countries [22]. Locational attributes are also contained in a critical price determinant group. Those represent accessibility and proximity to major public facilities and places [23-27], such as distances to downtown, commercial, educational, and transportation facilities. Evans underlined the distance to central business districts with highlighting the "access/space trade-off" model [28]. Job accessibility was also found to affect housing choice and price [29]. Transportation such as metro/railway networks [30-34] and bus rapid transit networks [35] was also influential. Further, accessibility of quality schools strongly influenced price [36,37]. Environmental amenities such as public open spaces and urban park [38-41], air quality [42,43], and water quality $[44,45]$ were also significant price determinants for housing choice and price.

\subsection{Empirical Review of Seismic Risk and Property Values}

Theoretically, the consideration that a seismic factor affects property prices indicates change in expected utility [46], which means that differentials in property values reflect the perception and assessment of seismic risk in the market. Multiple studies have examined how perceived seismic risks lead to price differentials in the housing market [4,46-49]. Brookshire et al. [46] investigated whether the risk of low-probability, high-loss events, such as earthquakes, is substantially perceived and reflected in the housing market. Data on housing markets in Los Angeles and San Francisco counties before and after the disclosure of earthquake hazard maps in 1974 demonstrate that the hedonic price gradient for safety is significant, which implies that the perception of seismic risk affects the real estate market through changes in expected utility. Beron et al. [4] measured the expected loss from earthquake risk by analyzing housing prices in the San Francisco Bay Area before and after the Loma Prieta earthquake in 1989. They discovered that perceived hazard risk significantly affected property values. However, the risk was overestimated before the Loma Prieta earthquake occurred. Nakagawa, Saito, and Yamaga [49] analyzed the 1998 hazard map of the Tokyo metropolitan area to investigate how the effect of earthquake risk on housing rent depends on the structure of the rental house. They discovered that housing rent was substantially lower in areas exposed to earthquake risk. Moreover, the rates are lower in high-risk areas for apartments built prior to the amendment of the Building Standard Law in 1981 to enhance the earthquake-resistant quality of buildings, compared to those built after the law. Hidano, Hosino, and Sugiura [47] applied a two-dimensional regression discontinuity design to investigate the effect of seismic hazard risk information on properties in Tokyo. They also observed that the prices of apartments in low-risk zones were significantly higher than those in high-risk zones and the effect of seismic risk was insignificant for newly built apartments.

Some studies have focused on how the occurrence of a seismic event affects an individual's perception of earthquake risk. Naoi, Seko, and Sumita [5] examined a hedonic pricing model to analyze an individual's assessment of seismic risk based on household panel data of hazard information from the Tokyo metropolitan area in 1989. They found that experiencing an earthquake can alter an individual's assessment of earthquake risk. This 
implies that individuals underestimate seismic risk if they have not experienced a recent occurrence. Their discovery also suggests that earthquake events can have a significant impact on property values soon after the event, even if information on hazard risk has been provided.

Most studies have analyzed data collected from areas where natural earthquakes have occurred several times in the past, and few studies have focused on induced earthquakes. Cheung, Wetherell, and Whitaker [50] estimated the impact of earthquakes on property values based on data from Oklahoma from 2006 to 2014. They found that property prices declined by between $3 \%$ and $4 \%$ after the occurrence of a moderate earthquake measuring 4 or 5 on the modified Mercalli intensity scale. Additionally, property values decreased by $9 \%$ or more after an earthquake with an intensity greater than 6 . Their findings are consistent with those of previous studies on the manifestation of earthquake risk perceptions. Ferreira, Liu, and Brewer [51] examined the impact of seismic risk perception from wastewater injection, which is known to potentially induce earthquakes. They found that nearby earthquakes significantly increased the perceived risk, but their effect was limited to areas within $2 \mathrm{~km}$ of the injection well. The effects of various natural hazards, such as the effects of floods [52-57], volcanoes, and hurricanes [3,58] on property markets, have been investigated in numerous studies.

\section{Research Methods}

\subsection{Site Selection}

Pohang, a city with a population of 500,000 in southeast Korea, was selected for this study because the region had never experienced earthquakes before the induced seismicity on 15 November 2017. Thus, market participants had few predictions about the potential occurrence of an earthquake. The city was selected to examine how the newly recognized earthquake potential is reflected in the housing market by comparing housing prices before and after the earthquake.

\subsection{Analytical Model}

Statistical analysis was conducted using a hedonic pricing model and a DID model to measure the seismic effects on housing prices in accordance with the geographic locations of housing before and after the earthquake. In the hedonic model, the price of individual housing included the embedded value of property attributes, which were estimated by regressing the market price of the asset as an observable property variable. In this case, structural and locational attributes are generally considered housing characteristics to be analyzed. Structural attributes refer to the physical characteristics of a building, such as the size of the house, number of floors, and number of rooms. Locational attributes primarily consider the distance to public centers or recreational facilities, such as central business districts (CBDs) or public parks.

This study focused on market changes after the earthquake; therefore, a time dummy was included as an independent variable. In addition, to compare the differences in market changes after the earthquake by distance from the epicenter, a categorical variable based on $3 \mathrm{~km}$ increments from the epicenter was included in the set of locational variables. These were the hedonic regression models used to investigate price determinants in this study:

$$
\begin{gathered}
y_{i}=\beta_{0}+\sum_{k} \beta_{k} x_{k, i}+\alpha_{e} I_{e}+\varepsilon_{i} \text { where } \varepsilon_{i} \sim N\left(0, \sigma^{2}\right) \\
y_{i}=\beta_{0}+\sum_{k} \beta_{k} x_{k, i}+\sum_{j}\left(\beta_{j}+\alpha_{j} I_{e}\right) d_{j, i}+\varepsilon_{i} \text { where } \varepsilon_{i} \sim N\left(0, \sigma^{2}\right)
\end{gathered}
$$

In the equation above, $y_{i}$ is the dependent variable, $x_{k}$ and $d_{j}$ are the independent variables, and $\varepsilon_{i}$ is the error term. The dependent variable is a value obtained by taking the natural $\log$ of the market price of the apartment. $\beta_{0}, \beta_{k}$, and $\beta_{j}$ are regression coefficients for each variable. $\beta_{0}$ is a constant term, and $\beta_{k}$ is the coefficient of the general control variable. Here, $x_{k, i}$ includes both structural and locational attributes. In the second model, $\beta_{j}$ refers to the average location effect (before the earthquake) by the distance group from 
the epicenter. $d_{j}$ is a categorical variable based on $3 \mathrm{~km}$ increments (less than $3 \mathrm{~km}, 3-6 \mathrm{~km}$, 6-9 km, 9-12 km, 12-15 km, 15-18 km, and over $18 \mathrm{~km}$ ) from the epicenter. As $\beta_{j}$ reflects the aggregate locational effects before the earthquake, the coefficients may not be relevant to the geographical distribution of seismic risk. $I_{e}$ is an indicator variable with a value of 0 before and after the earthquake date (15 November 2017). In Model (1), as the coefficient $\alpha_{e}$ is defined on the time indicator, it becomes a simple time dummy effect. This indicates average change in local real estate values since the earthquake event. In Model (2), $\alpha_{j}$ represents the changes in the coefficient values after the earthquake. It captures how much the locational effects change after the earthquake. The difference in asset value change by epicenter group can be observed by comparing the estimated values $\alpha_{j}$. If the seismic risk negatively impacts local housing values significantly, the estimated coefficients for post-event distance dummies were shown to decrease with the distance from the epicenter.

\subsection{Data Collection}

Data used in this study were obtained from Statistics Korea; the apartment transaction price data was provided by the MOLIT (Ministry of Land, Infrastructure, and Transport) of Korea and Naver Real Estate, Korea's largest real estate information service provider. We found that a total of 4201 apartments were transacted in Pohang from 14 November 2016 to 16 November 2018-one year preceding and following the earthquake on 15 November 2017 (Figure 1). This date range was selected due to the volume of samples and to avoid potential sample bias. Extending the time length would lead to an increased number of samples; however, the possibility that non-seismic temporal factors caused disturbances in the housing value data may also have increased. Data including only short-term changes before and after the earthquake was used in this study; thus, non-seismic temporal factors affecting housing values were expected to remain limited to short-term economic changes in business cycles or interest rates. However, the effects of those factors were already captured by the temporal dummy in our framework; therefore, the model equation did not need to include those variables. In addition, we provided results from a shorter period range of data for the robustness test (Section 4.5). The transaction price, transaction date, and location of the apartment were used as dependent variables based on the real estate transaction price dataset provided by the Korean Ministry of Land, Infrastructure, and Transport of the Republic of Korea. Additionally, to improve the accuracy of the quantitative analysis, the transaction price was adjusted to the rate of change in the CPI by year according to the difference in transaction timing. Moreover, apartments completed after the Pohang earthquake were excluded from the analysis. The apartment type was selected because it is the predominant residential style in Pohang, accounting for $68 \%$ of all housing units (National Statistics: http:/ / kosis.kr/statisticsList/statisticsListIndex.do?menuId=M_01_0

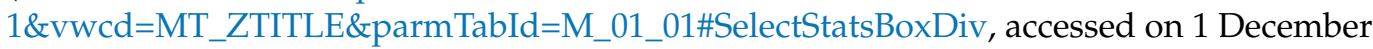
2020). Furthermore, the structural attributes of apartments are relatively well organized by several common and observable variables that can be used in the hedonic pricing model. Compared to apartments, single-family houses are known to have more complicated amenities, interior decorations, and features, which are difficult to codify or consolidate in a dataset [14]. 


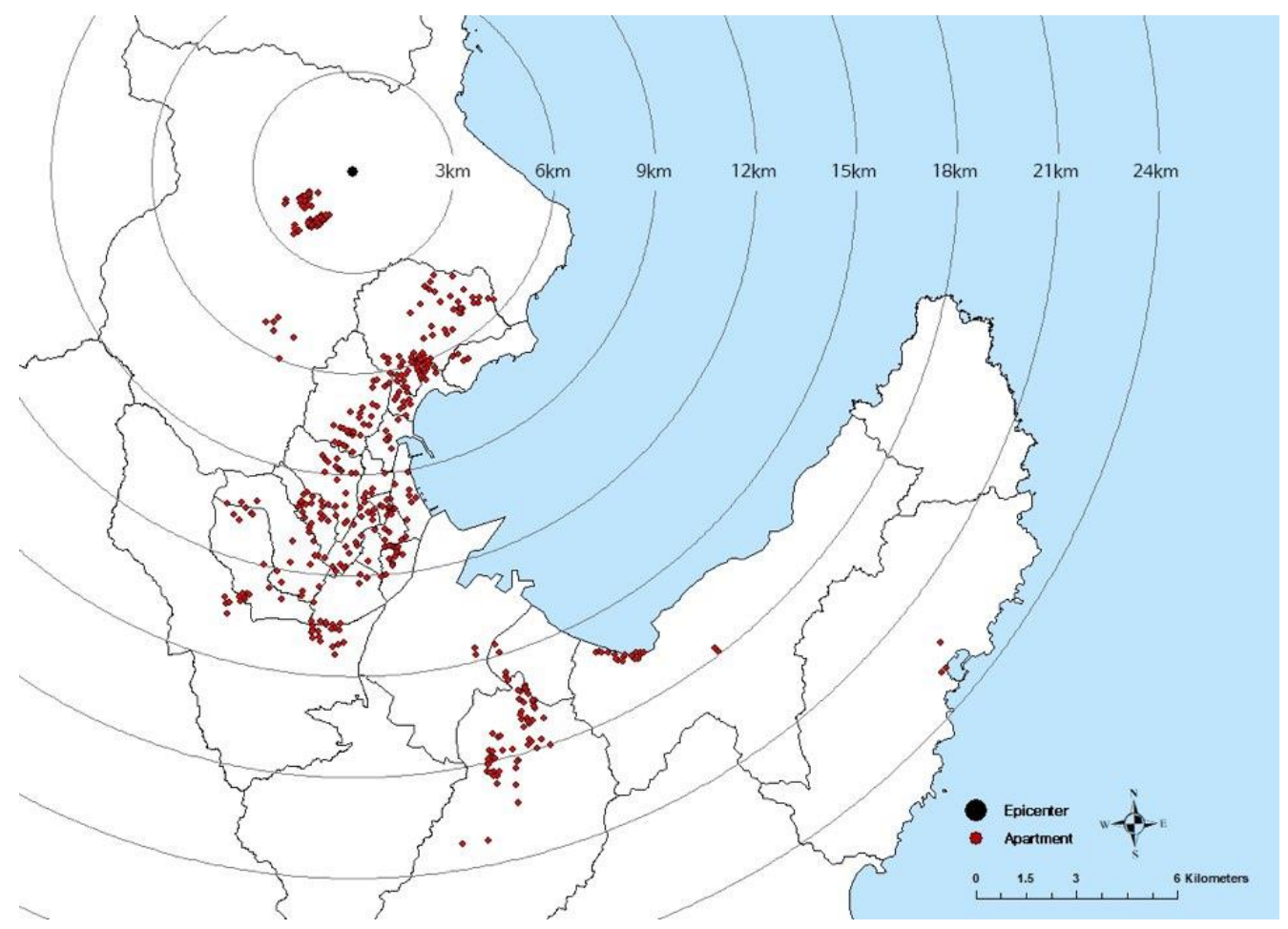

Figure 1. The distribution map of Pohang apartments for this study.

\subsection{Variable Setting}

The model used in this study used various characteristics of the apartment as a control variable for the regression analysis. The price of an apartment is a dependent variable and was naturalized and applied in the regression analysis. The unit area is the square meters of the property, and the elapsed year is calculated by subtracting the construction year from the transaction year. Complex size refers to the number of households in the apartment complex where the asset is located and may indicate the size of the accumulation effect in the context of urban economics. An anti-seismic system is a dichotomous variable for whether an earthquake-resistant design is constructed. In Korea, the law was revised in 2005 to make seismic design mandatory for buildings with more than three stories or 1000 square meters. Therefore, in this study, an indicator variable that distinguished whether a building was built after 2005 was used as a dichotomous variable for seismic design. Hallway type is a categorical variable that indicates whether the hallway of an apartment is a corridor-type, stair-type, or complex-type. In the regression analysis, two dummy variables were used to distinguish between corridor and complex types based on the staircase type (the coefficient value was 0 ). The heating type is a categorical variable that indicates the type of heating, whether individual, central, or district. In the regression analysis, dummy variables that distinguished between individual heating and district heating were included based on central heating. The floor area ratio (FAR) refers to the ratio of the gross floor area of the building to the land area. As this increased, the stake on the land decreased. The building coverage ratio (BCR) refers to the ratio of the building area to the land area. The average parking lot variable indicates the total number of parking lots in the complex divided by the number of households. The highest top-floor level in the complex refers to the number of floors in the tallest building in the complex.

Next, the locational attributes, such as the distance from the apartment to the closest kindergarten, elementary school, middle school, high school, university, and CBD, were calculated by the Euclidean distance between the latitude and longitude of each apartment, and the latitude and longitude of each facility. In urban economics, distance to the CBD is generally described as being related to commuting costs [59]. POSCO, Korea's largest steel manufacturer, is also the largest company located in Pohang. Distance to the CBD in this 
study used distance to the largest corporation (POSCO) as a proxy because a majority of the local economy in Pohang relies on the sales of POSCO and its partners or subcontractors, and POSCO employs the largest number of people. A distant CBD is known to have a clear negative effect, but POSCO is a steel company; thus, it also has a negative effect on the surrounding environment. Therefore, it is unclear whether the distance effect is positive or negative. There is no subway system in Pohang, and the city is equipped with an automobile-oriented transportation system, thus the distance from public transportation facilities was excluded from the locational variable. Information about the distance to the closest public park was also collected, but it was excluded from the control variable because it appeared to have a multicollinearity problem with other locational variables. However, the results of the quantitative analysis did not change for these variables. The definitions of these variables are presented in Table 1.

Table 1. Variable information.

\begin{tabular}{|c|c|c|c|}
\hline Category & Variables & Unit & Description \\
\hline Dependent variable & Price & local currency (10,000 won) & Transaction price (inflation adjusted) \\
\hline \multirow{13}{*}{ Structural effect } & Unit area & square meter & Size of unit area \\
\hline & Rooms & quantity & Number of rooms \\
\hline & Restrooms & quantity & Number of restrooms \\
\hline & Floor & floor level & Level of floor \\
\hline & Elapsed year & year & $\begin{array}{l}\text { Difference between transaction year } \\
\text { and completion year }\end{array}$ \\
\hline & Size of the complex & quantity & $\begin{array}{l}\text { Number of households in the } \\
\text { apartment complex }\end{array}$ \\
\hline & Hallway type & dummy & $\begin{array}{l}\text { Category: stair-type, aisle-type, } \\
\text { complex-type }\end{array}$ \\
\hline & Heating type & dummy & Category: central, unit, district \\
\hline & Anti-seismic system & dummy & $\begin{array}{l}\text { Existence of anti-seismic system } \\
\text { (constructed after 2005) }\end{array}$ \\
\hline & Floor area ratio & ratio & (Building area/land area) $* 100$ \\
\hline & Building coverage & ratio & (Total floor area/land area) $* 100$ \\
\hline & Average parking lot & quantity & $\begin{array}{l}\text { Average number of parking units per } \\
\text { household }\end{array}$ \\
\hline & Highest top floor level & floor level & Highest top floor level in the complex \\
\hline \multirow{6}{*}{ Locational effect } & Accessibility to kindergarten & meter & Distance to the closest kindergarten \\
\hline & $\begin{array}{l}\text { Accessibility to elementary } \\
\text { school }\end{array}$ & meter & $\begin{array}{l}\text { Distance to the closest elementary } \\
\text { school }\end{array}$ \\
\hline & Accessibility to middle school & meter & Distance to the closest middle school \\
\hline & Accessibility to high school & meter & Distance to the closest high school \\
\hline & Accessibility to university & meter & Distance to the closest university \\
\hline & Accessibility to CBD & meter & Distance to the largest corporation \\
\hline
\end{tabular}

The model used in this study classified transactions from earthquake epicenters by using categorical variables. This model divided the distance from the epicenter into $3 \mathrm{~km}$ units (regression coefficient value of 0 ) and divided all areas of Pohang into six zones using a $3 \mathrm{~km}$ distance unit. The location of the earthquake epicenter was determined by the Korea Meteorological Administration (latitude: $36.12^{\circ} \mathrm{N}$, longitude: $129.36^{\circ} \mathrm{E}$ ). Figure 1 illustrates the distribution of apartments in Pohang according to distance from the epicenter.

According to the data, there are 64 apartment complexes with 9601 households within $3 \mathrm{~km}$ of the epicenter. Within $3 \mathrm{~km}$, there are 51 apartment complexes with 4098 households. For 3-6 km, 6-9 km, 9-12 km, 12-15 km, 15-km, and over $18 \mathrm{~km}$, there are 23,572 (53 complexes), 26,584 (90 complexes), 21,805 (110 complexes), 12,365 (49 complexes), 8546 (65 complexes), and 3277 (19 complexes) households, respectively. Data for apartment complexes completed before the Pohang earthquake are as follows. 


\section{Finding and Discussion}

\subsection{Descriptive Statistics}

The descriptive statistics of the collected data are indicated in Tables 2 and 3. The average price of an apartment in Pohang is 190 million won, which is approximately 158 thousand dollars (based on an exchange rate from 13 July 2020). In Korea, family units primarily reside in apartments, with an average size of approximately 83 square meters. The average elapsed years is approximately 12 years, and a minimum value of 0 indicates that there are apartment complexes under analysis incorporated at the earliest point. Apartments completed after the earthquake were not included in the sample. The average apartment complex accommodates 725 households.

Table 2. Descriptive statistics.

\begin{tabular}{lrrrr}
\hline Variables & Mean & $\begin{array}{r}\text { Standard } \\
\text { Deviation }\end{array}$ & Min & Max \\
\hline Price & 19,015 & 8524.59 & 1898.52 & $56,098.19$ \\
Unit area $\left(\mathrm{m}^{2}\right)$ & 83.08 & 26.42 & 17.33 & 243.25 \\
Rooms & 3.05 & 0.53 & 1.00 & 7.00 \\
Restrooms & 1.75 & 0.45 & 1.00 & 3.00 \\
Floor level & 10.16 & 6.83 & 1.00 & 47.00 \\
Elapsed years & 12.08 & 6.58 & 0.00 & 31.00 \\
Floor area ratio & 257.32 & 54.57 & 73.00 & 408.00 \\
Building coverage ratio & 24.056 & 12.42 & 6.00 & 84.00 \\
Complex size & 725.89 & 537.27 & 10.00 & 2130.00 \\
Average parking lot & 1.12 & 0.32 & 0.08 & 2.43 \\
Highest of top floor & 20.89 & 8.15 & 5.00 & 48.00 \\
Distance to kindergarten & 413.59 & 238.97 & 11.82 & 1231.43 \\
Distance to elementary school & 475.90 & 246.80 & 31.61 & 1213.95 \\
Distance to middle school & 914.70 & 630.95 & 93.57 & 3283.47 \\
Distance to high school & 1084.98 & 753.08 & 109.07 & $11,000.91$ \\
Distance to university & 2871.09 & 2661.24 & 111.07 & $18,077.66$ \\
Distance to CBD & 6712.02 & 2341.55 & 2127.90 & $22,010.46$ \\
\hline Number of samples & & & & \\
\hline
\end{tabular}

Table 3. Dummy variables.

\begin{tabular}{llll}
\hline Variables & Types & Number & Proportion (\%) \\
\hline \multirow{4}{*}{ Hallway type } & Stair-type & 3729 & 88.76 \\
& Aisle-type & 133 & 3.17 \\
& Complex-type & 339 & 8.07 \\
& Total & 4.201 & 100.00 \\
\hline \multirow{2}{*}{ Heating type } & Unit & 3899 & 92.81 \\
& Central & 177 & 4.21 \\
& District & 125 & 2.98 \\
& Total & 4.201 & 100.00 \\
\multirow{3}{*}{ Anti-seismic system } & Anti-seismic & 2348 & 55.89 \\
& Non & 1853 & 44.11 \\
& Total & 4.201 & 100.00 \\
\hline
\end{tabular}

Regarding locational attributes, we observed that the average distance between educational institutions increased with the age of the students. The average distance increased from $413 \mathrm{~m}$ for kindergartens to $475 \mathrm{~m}$ for elementary schools, and 914, 1084, and $2871 \mathrm{~m}$ for middle schools, high schools, and universities, respectively. There are fewer educational institutions above elementary level, whereas kindergartens and elementary schools are greater in number and are distributed around the apartment complexes for convenience. 
Finally, the company employing the largest number of people is located at an average distance of $6712 \mathrm{~m}$ from employees.

\subsection{Regression Results}

This study first presents the results of an empirical analysis of a model that does not include the effect of distance to the epicenter. First, whether the model properly controls structural and locational attributes other than the earthquake effect can be determined. Second, it is possible to effectively examine the endogeneity among independent variables included in the model. This model shows how real estate prices in the region changed, on average, after the earthquake. The equation used to estimate the hedonic model was the same as that in (1), presented in Section 3.1.

Table 4 presents the benchmark model results. First, considering that it is a hedonic model, the explanatory power was notably high, despite the large number of samples (4201) with an R-squared value of approximately $89 \%$. Second, most of the major housing attributes were significant (the alternative hypothesis is adopted even under the $99.99 \%$ null hypothesis adoption rate) and had a generally well-known impact.

Table 4. Regression results.

\begin{tabular}{lc}
\hline Independent Variable & Result \\
\hline Unit area (log) & $0.74943(36.00)^{* *}$ \\
Floor level & $0.00263(5.81)^{* *}$ \\
Elapsed year & $-0.02570(-30.21)^{* *}$ \\
Number of rooms & $0.00542(0.58)^{* *}$ \\
Number of restrooms & $0.10573(11.39)^{* *}$ \\
Hall type: complex (dummy) & $0.13331(7.82)^{* *}$ \\
Hall type: aisle (dummy) & $-0.12680(-11.96)^{* *}$ \\
Heating type: unit (dummy) & $0.37154(22.86)^{* *}$ \\
Heating type: district (dummy) & $-0.06104(-2.98)^{* *}$ \\
Floor-area ratio & $-0.00108(-16.50)^{* *}$ \\
Building coverage ratio & $-0.00083(-2.80)^{* *}$ \\
Average parking lot & $0.20811(14.10)^{* *}$ \\
Anti-seismic system (dummy) & $0.03726(3.20)^{* *}$ \\
Number of households in the complex & $0.00000(0.11)^{*}$ \\
Highest top floor level in the complex & $\left.0.00602(9.74)^{* *}\right)^{* *}$ \\
Distance to kindergarten & $-0.00008(-4.83)^{* *}$ \\
Distance to elementary school & $-0.00014(-8.89)^{* *}$ \\
Distance to middle school & $-0.00007(-12.08)^{* *}$ \\
Distance to high school & $0.00005(11.32)^{* *}$ \\
Distance to university & $-0.00003(-22.56)^{* *}$ \\
Distance to CBD & $-0.00004(-28.71)^{* *}$ \\
Post-event dummy & $-0.03909(-7.08)^{* *}$ \\
Constant & $6.94361(114.68)^{* *}$ \\
\hline MAE & 0.1446 \\
\hline MSE & 0.0294 \\
\hline RMSE & 0.1716 \\
\hline R-squared & 0.8903 \\
\hline Number of observations & 4201 \\
\hline Not T-sta \\
\hline
\end{tabular}

Note: T-statistics are in parentheses. ${ }^{* *}$ denotes the $1 \%$ significance level. A variance influence factor (VIF) was used to verify multicollinearity between the independent variables in this model. The VIF values for most variables did not exceed 5.

For example, the value of a house depreciates as the number of elapsed years increases, and the value increases as the number of parking spaces increases. In addition, there is a premium for houses built after anti-seismic design became mandatory, even before the earthquake occurred. The intuitiveness and high explanatory power of the estimated coefficients indicate that the model can properly control the characteristics of 
local apartments. Third, the coefficient value of the post-event dummy variable was -0.039 , which indicates that there was an average price drop of approximately $4 \%$ per apartment sold after the earthquake, considering that the dependent variable was the natural $\log$ of the apartment price. This is simply a synthesis of the overall market changes over a period after the earthquake, and it is difficult to determine whether the effect of the earthquake was properly estimated. Nevertheless, this result clearly demonstrates that a significant change occurred between the months before the earthquake and the year following the earthquake.

\subsection{Difference-in-Differences Model}

This section empirically analyzes the market changes before and after the earthquake based on the distance from the seismic epicenter using a DID model. The model used in the previous section showed, on average, how the prices of apartments in the area changed since the earthquake occurred. However, it is difficult to attribute the average price change to an earthquake because real estate prices can be affected not only by earthquakes, but also by other economic or environmental changes. These economic or environmental changes can have a homogeneous impact on the local property market. Conversely, the effect of earthquakes is likely to differ depending on the distance to the epicenter, as implied in previous studies (e.g., Naoi, Seko, and Sumita 2009). The seismic effect can be indirectly estimated by comparing whether the asset value changes after the earthquake depending on its distance from the epicenter because an additional reduction in the asset value in areas closer to the epicenter, compared to areas farther away, is likely due to earthquakes. This refers to the results of the analysis of Equation (2) in Section 3.1. The distance from the epicenter was divided into $3 \mathrm{~km}$ increments (within $3 \mathrm{~km}, 3-6 \mathrm{~km}, 6-9 \mathrm{~km}$, 9-12 km, 12-15 km, 15-18 km, and $>18 \mathrm{~km}$ ). The pre-event dummy variables represented the average difference in apartment prices by distance group during the pre-earthquake period. The apartment market within $3 \mathrm{~km}$ of the earthquake was the basis point (i.e., a coefficient value of 0 ). The post-event dummy variables indicated the percentage changes in property values after the earthquake (compared with the pre-earthquake period) by the distance group.

Table 5 presents the results of the analysis. In summary, the results clearly demonstrated that being located closer to the epicenter of the earthquake led to greater volatility of asset prices after the earthquake. More specifically, being located closer to the epicenter indicated greater price reductions. In regions within $3 \mathrm{~km}$, which is closest to the epicenter, the price drop was approximately $-22 \%$, which is significantly lower than that of other regions and the average time effect estimated in the previous model. After the earthquake, the price gradually increased as the distance to the epicenter increased, and when the distance was over $12 \mathrm{~km}$, the null hypothesis $\left(H_{0}: \alpha_{k}=0\right)$ that there was a significant price change after the earthquake cannot be dismissed, even at a low confidence level. This result clearly indicates that apartment prices in areas closer to the epicenter reduced further after the earthquake. The post-event dummy represents the average asset value change that occurred after the earthquake (compared with before the earthquake), and the inability to dismiss the null hypothesis indicates that the asset value change after the earthquake is not apparent. If we assume that such a null hypothesis group (i.e., a group far from the epicenter) is exposed equally to economic changes, except for the earthquake effect and the group that is relatively close to the epicenter, it can be inferred that the size of the seismic effect was significant enough to reject the null hypothesis. It is possible that even the group for which the null hypothesis could not be dismissed experienced an earthquake effect. In this case, other economic changes (other than earthquakes) are expected to have caused the increased housing value; thus, the offset of the two opposite effects makes the estimated coefficient insignificant. In this case, the earthquake effect was greater in all regions. 
Table 5. Regression results.

\begin{tabular}{|c|c|c|c|}
\hline \multicolumn{3}{|c|}{ Independent Variable } & Result \\
\hline \multicolumn{3}{|l|}{ Unit area $(\log )$} & $0.75927(40.43) * *$ \\
\hline \multicolumn{3}{|l|}{ Floor level } & $0.00223(5.55)^{* *}$ \\
\hline \multicolumn{3}{|l|}{ Elapsed year } & $-0.02321(-29.26)^{* *}$ \\
\hline \multicolumn{3}{|c|}{ Number of rooms } & $-0.00053(-0.06)$ \\
\hline \multicolumn{3}{|c|}{ Number of restrooms } & $0.09926(11.99)^{* *}$ \\
\hline \multicolumn{3}{|c|}{ Hall type: complex (dummy) } & $0.03595(2.25) *$ \\
\hline \multicolumn{3}{|c|}{ Hall type: aisle (dummy) } & $-0.04477(-4.48)^{* *}$ \\
\hline \multicolumn{3}{|c|}{ Heating type: unit (dummy) } & $0.26234(17.35)^{* *}$ \\
\hline \multicolumn{3}{|c|}{ Heating type: district (dummy) } & $-0.11341(-5.67)^{* *}$ \\
\hline \multicolumn{3}{|c|}{ Floor area ratio } & $-0.0071(-11.13)^{* *}$ \\
\hline \multicolumn{3}{|c|}{ Building coverage ratio } & $0.00037(1.33)$ \\
\hline \multicolumn{3}{|c|}{ Average parking lot } & $0.15729(11.64) * *$ \\
\hline \multicolumn{3}{|c|}{ Anti-seismic system (dummy) } & $0.08592(7.98)^{* *}$ \\
\hline \multicolumn{3}{|c|}{ Number of households in the complex } & $-0.00001(-1.52)$ \\
\hline \multicolumn{3}{|c|}{ Highest top floor level in the complex } & $0.00926(15.96)^{* *}$ \\
\hline \multicolumn{3}{|c|}{ Distance to kindergarten } & $-0.00012(-7.26)^{* *}$ \\
\hline \multicolumn{3}{|c|}{ Distance to elementary school } & $-0.00010(-7.27)^{* *}$ \\
\hline \multicolumn{3}{|c|}{ Distance to middle school } & $-0.00007(-12.87)^{* *}$ \\
\hline \multicolumn{3}{|c|}{ Distance to high school } & $-0.00002(-3.42) * *$ \\
\hline \multicolumn{3}{|c|}{ Distance to university } & $-0.00004(-13.97) * *$ \\
\hline \multicolumn{3}{|c|}{ Distance to CBD } & $0.00002(8.47) * *$ \\
\hline \multirow{13}{*}{$\begin{array}{l}\text { Distance from the } \\
\text { epicenter }\end{array}$} & \multirow{6}{*}{ Dummy variables } & $3 \sim 6 \mathrm{~km}$ & $0.15022(5.96)^{* *}$ \\
\hline & & $6 \sim 9 \mathrm{~km}$ & $0.32366(11.41) * *$ \\
\hline & & $9 \sim 12 \mathrm{~km}$ & $0.51681(16.61)^{* *}$ \\
\hline & & $12 \sim 15 \mathrm{~km}$ & $0.42549(13.73) * *$ \\
\hline & & $15 \sim 18 \mathrm{~km}$ & $0.39000(9.54)^{* *}$ \\
\hline & & Over 18 km & $0.36520(8.80)^{* *}$ \\
\hline & & $0 \sim 3 \mathrm{~km}$ & $-0.21939(-6.49) * *$ \\
\hline & & $3 \sim 6 \mathrm{~km}$ & $-0.07200(-8.31)^{* *}$ \\
\hline & & $6 \sim 9 \mathrm{~km}$ & $-0.07421(-6.94) * *$ \\
\hline & Post-event dummies & $9 \sim 12 \mathrm{~km}$ & $-0.01685(-1.69)$ \\
\hline & & $12 \sim 15 \mathrm{~km}$ & $0.00748(0.60)$ \\
\hline & & $15 \sim 18 \mathrm{~km}$ & $0.00143(0.07)$ \\
\hline & & Over 18 km & $-0.00364(-0.11)$ \\
\hline Constant & & & $6.13508(89.23)^{* *}$ \\
\hline MAE & & & 0.1316 \\
\hline MSE & & & 0.0231 \\
\hline RMSE & & & 0.1523 \\
\hline R-squared & & & 0.9139 \\
\hline Number of observ & & & 4201 \\
\hline
\end{tabular}

Note: T-statistics are in parentheses. ${ }^{* *}$ denotes the $1 \%$ significance level; ${ }^{*}$ denotes the $5 \%$ significance level.

Additionally, there was a marked increase in explanatory power compared to the simple model in the previous section. In the simplified model, the R-squared value was 0.89 ; however, considering the difference in asset value by distance from the epicenter, the $\mathrm{R}$-squared value increased to 0.913 . This is interpreted to be because the changes in asset values before and after the earthquake differed significantly based on the distance from the epicenter.

\subsection{Preference for Anti-Seismic Building}

The preference most directly associated with the earthquake experience is the inclusion of anti-seismic systems. If the likelihood of an earthquake in the future is low, market participants are unlikely to give a high premium to assets with anti-seismic systems. 
Because the utilization value of the anti-seismic system is limited to the occurrence of an earthquake, the intention to pay for it will essentially take the form of the expected value multiplied by the expected probability of an earthquake occurring and the value of the damage preserved by the anti-seismic system in the event of an earthquake. In other words, if people's expectations about the probability of an earthquake change (Brookshire et al. 1985), their intention to pay for the anti-seismic system is likely to increase. In particular, as in the case of this study, if an earthquake occurs in an area with no prior experience of earthquakes, the change in their preference structure can be estimated more clearly.

This section further examines whether preferences for anti-seismic buildings have changed since the earthquake. The model for this is as follows:

$$
y_{i}=\beta_{0}+\sum_{k} \beta_{k} x_{k, i}+\left(\beta_{a}+\alpha_{a} I_{e}\right) x_{a, i}+\sum_{j}\left(\beta_{j}+\alpha_{j} I_{e}\right) d_{j, i}+\varepsilon_{i} \text { where } \varepsilon_{i} \sim N\left(0, \sigma^{2}\right)
$$

In the above model, $\beta_{a}$ and $\alpha_{a}$ are the coefficients of the anti-seismic building. $\beta_{a}$ is the coefficient value before the earthquake and $\alpha_{a}$ is the variation in the coefficient after the earthquake. The rest of the denotations are identical to those in Models (1) and (2).

The results of the model analysis are summarized in Table 6. First, assets with antiseismic systems had significant premiums even before the earthquake, indicating that the pre-event dummy coefficient value of the anti-seismic building was approximately 0.06 , and a premium of approximately $6 \%$ existed even before the earthquake, compared to assets without an anti-seismic system. Interestingly, this value increased significantly after the earthquake. The coefficient value of the post-event dummy of the anti-seismic building was 0.055 , which indicates that the premium charged to the anti-seismic building after the earthquake almost doubled. As discussed earlier, this may be a result of changes in people's expectations regarding the probability of an earthquake in the future.

Table 6. Regression results.

\begin{tabular}{ll}
\hline Independent Variable & \multicolumn{1}{c}{ Result } \\
\hline Unit area (log) & $0.75988(40.59)^{* *}$ \\
Floor level & $0.00223(5.59)^{* *}$ \\
Elapsed year & $-0.02339(-29.55)^{* *}$ \\
Number of rooms & $-0.00136(-0.16)$ \\
Number of restrooms & $0.09803(11.87)^{* *}$ \\
Hall type: complex (dummy) & $0.03631(2.28)^{*}$ \\
Hall type: aisle (dummy) & $-0.04304(-4.32)^{* *}$ \\
Heating type: unit (dummy) & $0.26106(17.31)^{* *}$ \\
Heating type: district (dummy) & $-0.11647(-5.84)^{* *}$ \\
Floor area ratio & $-0.00072(-11.25)^{* *}$ \\
Building coverage ratio & $0.00039(1.42)^{*}$ \\
Average parking lot & $0.15494(11.49)^{* *}$ \\
Anti-seismic (dummy) & $0.06291(5.42)^{* *}$ \\
Anti-seismic system (post-event dummy) & $0.05459(5.21)^{* *}$ \\
Number of households in the complex & $-0.00001(-1.35)$ \\
Highest top floor level in the complex & $0.00924(15.98)^{* *}$ \\
Distance to kindergarten & $-0.00012(-7.13)^{* *}$ \\
Distance to elementary school & $-0.00011(-7.41)^{* *}$ \\
Distance to middle school & $-0.00007(-12.92)^{* *}$ \\
Distance to high school & $-0.00002(-3.31)^{* *}$ \\
Distance to university & $-0.00004(-14.11)^{* *}$ \\
Distance to CBD & $0.00002(8.46)^{* *}$ \\
\hline
\end{tabular}


Table 6. Cont.

\begin{tabular}{|c|c|c|c|}
\hline Independent Vari & & & Result \\
\hline \multirow{13}{*}{$\begin{array}{l}\text { Distance from the } \\
\text { epicenter }\end{array}$} & \multirow{6}{*}{ Dummy variables } & $3 \sim 6 \mathrm{~km}$ & $0.16040(6.37)^{* *}$ \\
\hline & & $6 \sim 9 \mathrm{~km}$ & $0.32952(11.64)^{* *}$ \\
\hline & & $9 \sim 12 \mathrm{~km}$ & $0.52202(16.82)^{* *}$ \\
\hline & & $12 \sim 15 \mathrm{~km}$ & $0.43853(14.14) * *$ \\
\hline & & $15 \sim 18 \mathrm{~km}$ & $0.39263(9.64)^{* *}$ \\
\hline & & Over $18 \mathrm{~km}$ & $0.36406(8.80)^{* *}$ \\
\hline & \multirow{7}{*}{ Post-event dummies } & $0 \sim 3 \mathrm{~km}$ & $-0.23098(-6.84) * *$ \\
\hline & & $3 \sim 6 \mathrm{~km}$ & $-0.10975(-9.74) * *$ \\
\hline & & $6 \sim 9 \mathrm{~km}$ & $-0.09600(-8.38)^{* *}$ \\
\hline & & $9 \sim 12 \mathrm{~km}$ & $-0.03840(-3.56)^{* *}$ \\
\hline & & $12 \sim 15 \mathrm{~km}$ & $-0.03890(-2.54) *$ \\
\hline & & $15 \sim 18 \mathrm{~km}$ & $-0.01896(-0.87)$ \\
\hline & & Over $18 \mathrm{~km}$ & $-0.00910(-0.28)$ \\
\hline \multicolumn{3}{|l|}{ Constant } & $6.14818(89.64)^{* *}$ \\
\hline \multicolumn{3}{|l|}{ MAE } & 0.1305 \\
\hline \multicolumn{3}{|l|}{ MSE } & 0.023 \\
\hline \multicolumn{3}{|l|}{ RMSE } & 0.1518 \\
\hline \multicolumn{3}{|l|}{ R-squared } & 0.9145 \\
\hline \multicolumn{3}{|c|}{ Number of observations } & 4201 \\
\hline
\end{tabular}

\subsection{Robustness Test}

This section provides the results of narrowing the analysis period to ensure the robustness of the quantitative analysis discussed above. The results of the previous analysis were from one year before and one year after the earthquake date (two years in total). This date range was selected for the purpose of collecting as many samples as possible while avoiding potential bias due to seasonal effects by controlling the length of the period to be analyzed. However, the longer analysis period led to a higher likelihood that the results will include market changes other than those caused by earthquakes. Therefore, the analysis result obtained by compressing the analysis object to months before and after the earthquake can be used as a robustness test.

Table 7 summarizes the results of the quantitative analysis within the period of analysis as the first and second years (total of two years) before and after the earthquake date. The implications of the results can be summarized as follows. First, as in the previous results, a closer distance to the epicenter after the earthquake led to greater decline in asset prices. The change in asset value after the earthquake was unclear (the null hypothesis cannot be dismissed) in areas beyond $12 \mathrm{~km}$ from the epicenter. In addition, even if the analysis object was compressed, it was observed that the preference for anti-seismic structures increased after the earthquake. In conclusion, even if the object of analysis was compressed, the implications of the quantitative results discussed above are consistent.

Table 7. Regression results (robustness).

\begin{tabular}{lll}
\hline Independent Variable & \multicolumn{1}{c}{ Result 1 } & \multicolumn{1}{c}{ Result 2 } \\
\hline Unit area (log) & $0.76049(32.19)^{* *}$ & $0.76025(32.20)^{* *}$ \\
Floor level & $0.00193(3.79)^{* *}$ & $0.00194(3.81)^{* *}$ \\
Elapsed year & $-0.02108(-20.81)^{* *}$ & $-0.02114(-20.87)^{* *}$ \\
Number of rooms & $-0.01518(-1.40)$ & $-0.01517(-1.40)$ \\
Number of restrooms & $0.10722(9.82)^{* *}$ & $0.10663(9.77)^{* *}$ \\
Hall type: complex (dummy) & $0.02362(1.16)$ & $0.02385(1.17)$ \\
Hall type: aisle (dummy) & $-0.01285(-0.98)$ & $-0.01236(-0.94)$ \\
Heating type: unit (dummy) & $0.24879(13.24)^{* *}$ & $0.24877(13.25)^{* *}$ \\
\hline
\end{tabular}


Table 7. Cont.

\begin{tabular}{|c|c|c|c|c|}
\hline \multicolumn{3}{|c|}{ Independent Variable } & Result 1 & Result 2 \\
\hline \multicolumn{3}{|c|}{ Heating type: district (dummy) } & $-0.11353(-4.44) * *$ & $-0.11484(-4.49) * *$ \\
\hline \multicolumn{3}{|c|}{ Floor area ratio } & $-0.00090(-10.60) * *$ & $-0.00091(-10.66) * *$ \\
\hline \multicolumn{3}{|c|}{ Building coverage ratio } & $-0.00037(-1.01)$ & $-0.00036(-0.98)$ \\
\hline \multicolumn{3}{|c|}{ Average parking lot } & $0.18099(9.99)^{* *}$ & $0.18096(9.99) * *$ \\
\hline \multicolumn{3}{|c|}{ Anti-seismic system (dummy) } & $0.10424(7.48) * *$ & $0.09325(6.19) * *$ \\
\hline \multicolumn{3}{|c|}{ Anti-seismic system (post-event dummy) } & & $0.02682(1.92)$ \\
\hline \multicolumn{3}{|c|}{ Number of households in the complex } & $-0.00003(-3.40) * *$ & $-0.00003(-3.39) * *$ \\
\hline \multicolumn{3}{|c|}{ Highest top floor level in the complex } & $0.01060(14.41)^{* *}$ & $0.01063(14.46) * *$ \\
\hline \multicolumn{3}{|c|}{ Distance to kindergarten } & $-0.00013(-5.90) * *$ & $-0.00013(-5.84) * *$ \\
\hline \multicolumn{3}{|c|}{ Distance to elementary school } & $-0.00011(-5.56) * *$ & $-0.00011(-5.63)^{* *}$ \\
\hline \multicolumn{3}{|c|}{ Distance to middle school } & $-0.00007(-9.85) * *$ & $-0.00007(-9.87)^{* *}$ \\
\hline \multicolumn{3}{|c|}{ Distance to high school } & $-0.00001(-2.26) *$ & $-0.00001(-2.25) *$ \\
\hline \multicolumn{3}{|c|}{ Distance to university } & $-0.00004(-12.23) * *$ & $-0.00004(-12.26) * *$ \\
\hline \multicolumn{3}{|c|}{ Distance to CBD } & $0.00002(5.88) * *$ & $0.00002(5.87) * *$ \\
\hline \multirow{13}{*}{$\begin{array}{l}\text { Distance from the } \\
\text { epicenter }\end{array}$} & \multirow{6}{*}{ Dummy variables } & $3 \sim 6 \mathrm{~km}$ & $0.13952(3.75) * *$ & $0.14465(3.88)^{* *}$ \\
\hline & & $6 \sim 9 \mathrm{~km}$ & $0.34346(8.36) * *$ & $0.34590(8.43) * *$ \\
\hline & & $9 \sim 12$ km & $0.54820(12.21)^{* *}$ & $0.54986(12.25) * *$ \\
\hline & & $12 \sim 15 \mathrm{~km}$ & $0.43721(9.88) * *$ & $0.44345(10.00) * *$ \\
\hline & & $15 \sim 18 \mathrm{~km}$ & $0.45401(8.00)^{* *}$ & $0.45424(8.01) * *$ \\
\hline & & Over 18 km & $0.48719(8.51)^{* *}$ & $0.48646(8.50)^{* *}$ \\
\hline & \multirow{7}{*}{$\begin{array}{l}\text { Post-event } \\
\text { dummies }\end{array}$} & $0 \sim 3 \mathrm{~km}$ & $-0.17240(-3.59) * *$ & $-0.17886(-3.72) * *$ \\
\hline & & $3 \sim 6 \mathrm{~km}$ & $-0.02277(-1.99) *$ & $-0.04215(-2.76)^{* *}$ \\
\hline & & $6 \sim 9 \mathrm{~km}$ & $-0.03957(-2.92) * *$ & $-0.04970(-3.42) * *$ \\
\hline & & $9 \sim 12 \mathrm{~km}$ & $-0.03029(-2.32) *$ & $-0.03987(-2.85) * *$ \\
\hline & & $12 \sim 15 \mathrm{~km}$ & $0.01933(1.23)$ & $-0.00409(-0.21)$ \\
\hline & & $15 \sim 18 \mathrm{~km}$ & $0.00635(0.22)$ & $-0.00233(-0.08)$ \\
\hline & & Over 18 km & $0.02681(0.65)$ & $0.02476(0.60)$ \\
\hline \multicolumn{3}{|l|}{ Constant } & $6.16482(67.36)^{* *}$ & $6.17118(67.42)^{* *}$ \\
\hline \multicolumn{3}{|l|}{ MAE } & 0.1349 & 0.1345 \\
\hline \multicolumn{3}{|l|}{ MSE } & 0.0202 & 0.0201 \\
\hline \multicolumn{3}{|l|}{ RMSE } & 0.1421 & 0.142 \\
\hline \multicolumn{3}{|l|}{ R-squared } & 0.9220 & 0.9221 \\
\hline \multicolumn{3}{|c|}{ Number of observations } & 2224 & 2224 \\
\hline
\end{tabular}

\section{Conclusions}

Our study analyzed the reduction in local housing values following the 2017 earthquake in Pohang, South Korea. We developed a DID-style hedonic price model and examined how the magnitude of devaluation after the perception of seismicity varied based on distance from the epicenter. Based on this framework, we estimated the controlled effects of perceived seismic risks on local housing markets.

Our results are summarized as follows. First, the average housing prices sharply reduced after the perception of seismic risk. Second, the effect of seismic risk on local housing values varied significantly depending on the distance from the epicenter. After the occurrence of an earthquake, the decline in housing values became increasingly severe for areas located closer to the epicenter. In particular, in areas within $3 \mathrm{~km}$ of the epicenter, approximately $20 \%$ housing devaluation was observed in the year following the earthquake, whereas changes in property values in areas beyond the $12 \mathrm{~km}$ radius from the epicenter were insignificant. This result also indicates that the subjective experience of earthquakes strongly influenced the assessment of future seismic risks. Third, preference for the utilization of anti-seismic systems increased significantly after seismicity. The utilization of an anti-seismic system is limited to the occurrence of an earthquake; thus, the willingness to pay for it can change based on individuals' expected loss from the occurrence of seismic events. The results show that preference for the utilization of anti-seismic assets increased significantly after the perceived seismic risk increased. 
The main contribution of this paper is that we examined the market reaction by using the effect of induced seismicity. Measuring market responses to seismicity is usually difficult to identify because most seismic events have historical records, and the seismic risks are already considered in the market value of housing. Since the city studied in this paper had never experienced seismicity before the event, the quantitative results should be a good reference for researchers and practitioners who hope to gauge the size or feature of market impacts of seismic risks.

Recently, efficient earthquake-resistant structures and advanced technologies have been used in successful housing development projects. Our results also showed that the market assessment for the anti-seismic system were affected by the occurrence of the earthquake, which implies that the actual necessity for the earthquake-resistant building is larger than it seems. The government should pay attention to publishing further detailed guidelines and regulations of construction laws for aseismic structures and systems.

One limitation of this paper is that we examined only apartment prices due to the lack of data. Unfortunately, there was no public data collecting the price of townhouses and villas. Although the apartment is the predominant residential style in Korea, roughly $40 \%$ of other housing types were not included in the empirical tests. It is possible that the effects of seismic risk are slightly different between housing types, which could cause a moderate under or over-estimation of the seismic effect. Thus, in future studies, the data coverage could be extended to townhouse and villa types to determine a more balanced estimation. In addition, the applicability of unconventional models such as machine learning algorithms or artificial neural networks has been rapidly growing due to the recent improvement in computing power. As some machine learning models can accurately estimate house prices even with the existence of housing submarkets [14], those innovative algorithms could applied for a more accurate estimation in the future studies.

Author Contributions: Conceptualization, J.H., H.J. and D.S.; Data curation, J.H. and H.J.; Formal analysis, J.H. and H.J.; Investigation, J.H. and H.J.; Methodology, J.H. and H.J.; Project administration, J.H. and D.S.; Resources, J.H. and H.J.; Software, J.H. and H.J.; Supervision, D.S.; Validation, J.H. and D.S.; Visualization, D.S. and S.Y.; Writing—original draft, J.H. and H.J.; Writing-review \& editing, D.S., J.H. and S.Y. All authors have read and agreed to the published version of the manuscript.

Funding: This work was supported by the Ministry of Education of the Republic of Korea and the National Research Foundation of Korea (NRF-2021S1A5A2A03063960).

Institutional Review Board Statement: Ethnical review and approval were waived for this study, as the research was conducted using information available to the general public and not collecting personal identification information.

Informed Consent Statement: Informed consent was obtained from all subjects involved in the study.

Data Availability Statement: The data of the apartment in this study are available on request from the database of MOLIT (Ministry of Land, Infrastructure, and Transport) and Naver Real Estate. The request for data can be found here: https://rt.molit.go.kr/ and https://land.naver.com/ (accessed on 1 December 2020).

Conflicts of Interest: There are no conflict of interest to declare.

\section{References}

1. Kim, K.-H.; Ree, J.-H.; Kim, Y.; Kim, S.; Kang, S.Y.; Seo, W. Assessing whether the 2017 M w 5.4 Pohang earthquake in South Korea was an induced event. Science 2018, 360, 1007-1009. [CrossRef] [PubMed]

2. Kim, K.-H.; Seo, W.; Han, J.; Kwon, J.; Kang, S.Y.; Ree, J.-H.; Kim, S.; Liu, K. The 2017 ML 5.4 Pohang earthquake sequence, Korea, recorded by a dense seismic network. Tectonophysics 2019, 774, 228306. [CrossRef]

3. Bernknopf, R.L.; Brookshire, D.S.; Thayer, M.A. Earthquake and volcano hazard notices: An economic evaluation of changes in risk perceptions. J. Environ. Econ. Manag. 1990, 18, 35-49. [CrossRef]

4. $\quad$ Beron, K.J.; Murdoch, J.C.; Thayer, M.A.; Vijverberg, W.P.M. An Analysis of the Housing Market before and after the 1989 Loma Prieta Earthquake. Land Econ. 1997, 73, 101. [CrossRef]

5. Naoi, M.; Seko, M.; Sumita, K. Earthquake risk and housing prices in Japan: Evidence before and after massive earthquakes. Reg. Sci. Urban Econ. 2009, 39, 658-669. [CrossRef] 
6. Court, A.T. Hedonic price indexes with automotive examples. In The Dynamics of Automobile Demand; General Motors Corporation: New York, NY, USA, 1939; pp. 99-117.

7. Lancaster, K.J. A New Approach to Consumer Theory. J. Polit. Econ. 1966, 74, 132-157. [CrossRef]

8. Rosen, S. Hedonic Prices and Implicit Markets: Product Differentiation in Pure Competition. J. Politi. Econ. 1974, 82, 34-55. [CrossRef]

9. Xiao, Y. Hedonic Housing Price Theory Review. In Urban Morphology and Housing Market; Springer: Berlin/Heidelberg, Germany, 2017; pp. 11-40.

10. Liao, W.-C.; Wang, X. Hedonic house prices and spatial quantile regression. J. Hous. Econ. 2012, 21, 16-27. [CrossRef]

11. Torres-Pruñonosa, J.; García-Estévez, P.; Prado-Román, C. Artificial Neural Network, Quantile and Semi-Log Regression Modelling of Mass Appraisal in Housing. Mathematics 2021, 9, 783. [CrossRef]

12. Peterson, S.; Flanagan, A. Neural Network Hedonic Pricing Models in Mass Real Estate Appraisal. J. Real Estate Res. 2009, 31, 147-164. [CrossRef]

13. Selim, H. Determinants of house prices in Turkey: Hedonic regression versus artificial neural network. Expert Syst. Appl. 2009, 36, 2843-2852. [CrossRef]

14. Hong, J.; Choi, H.; Kim, W.-S. A house price valuation based on the random forest approach: The mass appraisal of residential property in South Korea. Int. J. Strat. Prop. Manag. 2020, 24, 140-152. [CrossRef]

15. Seo, D.; Chung, Y.S.; Kwon, Y. Price Determinants of Affordable Apartments in Vietnam: Toward the Public-Private Partnerships for Sustainable Housing Development. Sustainability 2018, 10, 197. [CrossRef]

16. Jayantha, W.M.; Oladinrin, O.T. Bibliometric analysis of hedonic price model using CiteSpace. Int. J. Hous. Mark. Anal. 2019, 13, 357-371. [CrossRef]

17. Chung, Y.S.; Seo, D.; Kim, J. Price Determinants and GIS Analysis of the Housing Market in Vietnam: The Cases of Ho Chi Minh City and Hanoi. Sustainability 2018, 10, 4720. [CrossRef]

18. McMillen, D.P. Changes in the distribution of house prices over time: Structural characteristics, neighborhood, or coefficients? J Urban Econ. 2008, 64, 573-589. [CrossRef]

19. Kain, J.F.; Quigley, J.M. Measuring the value of housing quality. J. Am. Stat. Assoc. 1970, 65, 532-548. [CrossRef]

20. Sirmans, G.S.; Macdonald, L.; MacPherson, D.A.; Zietz, E.N. The Value of Housing Characteristics: A Meta Analysis. J. Real Estate Financ. Econ. 2006, 33, 215-240. [CrossRef]

21. Fuerst, F.; McAllister, P.; Nanda, A.; Wyatt, P. Does energy efficiency matter to home-buyers? An investigation of EPC ratings and transaction prices in England. Energy Econ. 2015, 48, 145-156. [CrossRef]

22. Kohlhase, J.E. The impact of toxic waste sites on housing values. J. Urban Econ. 1991, 30, 1-26. [CrossRef]

23. Li, H.; Wei, Y.D.; Yu, Z.; Tian, G. Amenity, accessibility and housing values in metropolitan USA: A study of Salt Lake County, Utah. Cities 2016, 59, 113-125. [CrossRef]

24. Hanushek, E.; Yilmaz, K. Household Location and Schools in Metropolitan Areas with Heterogeneous Suburbs; Tiebout, Alonso, and Government Policy; National Bureau of Economic Research: Cambridge, MA, USA, 2010. [CrossRef]

25. Heikkila, E.; Gordon, P.; Kim, J.I.; Peiser, R.B.; Richardson, H.W.; Dale-Johnson, D. What Happened to the CBD-Distance Gradient? Land Values in a Policentric City. Environ. Plan. A Econ. Space 1989, 21, 221-232. [CrossRef]

26. Henneberry, J. Transport investment and house prices. J. Prop. Valuat. Invest. 1998, 16, 144-158. [CrossRef]

27. Landau, U.; Prashker, J.N.; Hirsh, M. The Effect of Temporal Constraints on Household Travel Behavior. Environ. Plan. A Econ. Space 1981, 13, 435-448. [CrossRef]

28. Evans, A. Urban Economics: An Introduction/Alan W. Evans; B. Blackwell: Oxford, UK; New York, NY, USA, 1985.

29. Hwang, S.; Thill, J.-C. Delineating urban housing submarkets with fuzzy clustering. Environ. Plan. B Plan. Des. 2009, 36, 865-882. [CrossRef]

30. Bowes, D.R.; Ihlanfeldt, K.R. Identifying the Impacts of Rail Transit Stations on Residential Property Values. J. Urban Econ. 2001, 50, 1-25. [CrossRef]

31. Debrezion, G.; Pels, E.; Rietveld, P. The impact of rail transport on real estate prices: An empirical analysis of the Dutch housing market. Urban Stud. 2011, 48, 997-1015. [CrossRef]

32. Chwiałkowski, C.; Zydroń, A. The Impact of Urban Public Transport on Residential Transaction Prices: A Case Study of Poznań, Poland. ISPRS Int. J. Geo Inf. 2022, 11, 74. [CrossRef]

33. Chen, Y.; Yazdani, M.; Mojtahedi, M.; Newton, S. The impact on neighbourhood residential property valuations of a newly proposed public transport project: The Sydney Northwest Metro case study. Transp. Res. Interdiscip. Perspect. 2019, 3, 100070. [CrossRef]

34. Vichiensan, V.; Wasuntarasook, V.; Hayashi, Y.; Kii, M.; Prakayaphun, T. Urban Rail Transit in Bangkok: Chronological Development Review and Impact on Residential Property Value. Sustainability 2021, 14, 284. [CrossRef]

35. Munoz-Raskin, R. Walking accessibility to bus rapid transit: Does it affect property values? The case of Bogotá, Colombia. Transp. Policy 2010, 17, 72-84. [CrossRef]

36. Gibbons, S.; Machin, S. Valuing English primary schools. J. Urban Econ. 2003, 53, 197-219. [CrossRef]

37. Kilpatrick, J.A.; Hefner, F. House Price Impact of School District Choice; South Carolina Center for Applied Real Estate Education and Research: Columbia, SC, USA, 1998. 
38. Anderson, S.T.; West, S.E. Open space, residential property values, and spatial context. Reg. Sci. Urban Econ. 2006, 36, 773-789. [CrossRef]

39. Lutzenhiser, M.; Netusil, N.R. The effect of open spaces on a home's sale price. Contemp. Econ. Policy 2001, 19, 291-298. [CrossRef]

40. Nowak, D.J.; McPherson, E.G. Quantifying the impact of trees: The Chicago urban forest climate project. Unasylva 1993, 173, 39-44.

41. Tyrväinen, L. The amenity value of the urban forest: An application of the hedonic pricing method. Landsc. Urban Plan. 1997, 37, 211-222. [CrossRef]

42. Graves, P.; Murdoch, J.C.; Thayer, M.A.; Waldman, D. The Robustness of Hedonic Price Estimation: Urban Air Quality. Land Econ. 1988, 64, 220. [CrossRef]

43. Smith, V.K.; Huang, J.-C. Can Markets Value Air Quality? A Meta-Analysis of Hedonic Property Value Models. J. Politi. Econ. 1995, 103, 209-227. [CrossRef]

44. Michael, H.J.; Boyle, K.J.; Bouchard, R. Water Quality Affects Property Prices: A Case Study of Selected Maine Lakes. Maine Agricultural and Forest Experiment Station Report Number 398; University of Maine: Orono, MA, USA, 1996.

45. Steinnes, D.N. Measuring the economic value of water quality. Ann. Reg. Sci. 1992, 26, 171-176. [CrossRef]

46. Brookshire, D.S.; Thayer, M.A.; Tschirhart, J.; Schulze, W.D. A Test of the Expected Utility Model: Evidence from Earthquake Risks. J. Polit. Econ. 1985, 93, 369-389. [CrossRef]

47. Hidano, N.; Hoshino, T.; Sugiura, A. The effect of seismic hazard risk information on property prices: Evidence from a spatial regression discontinuity design. Reg. Sci. Urban Econ. 2015, 53, 113-122. [CrossRef]

48. McCluskey, J.J.; Rausser, G.C. Estimation of Perceived Risk and Its Effect on Property Values. Land Econ. 2001, 77, 42-55. [CrossRef]

49. Nakagawa, M.; Saito, M.; Yamaga, H. Earthquake risk and housing rents: Evidence from the Tokyo Metropolitan Area. Reg. Sci. Urban Econ. 2007, 37, 87-99. [CrossRef]

50. Cheung, R.; Wetherell, D.; Whitaker, S. Induced earthquakes and housing markets: Evidence from Oklahoma. Reg. Sci. Urban Econ. 2018, 69, 153-166. [CrossRef]

51. Ferreira, S.; Liu, H.; Brewer, B. The housing market impacts of wastewater injection induced seismicity risk. J. Environ. Econ. Manag. 2018, 92, 251-269. [CrossRef]

52. Troy, A.; Romm, J. Assessing the price effects of flood hazard disclosure under the California natural hazard disclosure law (AB 1195). J. Environ. Plan. Manag. 2004, 47, 137-162. [CrossRef]

53. Bin, O.; Polasky, S. Effects of flood hazards on property values: Evidence before and after Hurricane Floyd. Land Econ. 2004, 80, 490-500. [CrossRef]

54. Skantz, T.; Strickland, T. House Prices and a Flood Event: An Empirical Investigation of Market Efficiency. J. Real Estate Res. 1987, 2, 75-83. [CrossRef]

55. Kousky, C. Learning from Extreme Events: Risk Perceptions after the Flood. Land Econ. 2010, 86, 395-422. [CrossRef]

56. Atreya, A.; Ferreira, S.; Kriesel, W. Forgetting the Flood? An Analysis of the Flood Risk Discount over Time. Land Econ. 2013, 89, 577-596. [CrossRef]

57. Bin, O.; Landry, C.E. Changes in implicit flood risk premiums: Empirical evidence from the housing market. J. Environ. Econ. Manag. 2012, 65, 361-376. [CrossRef]

58. Carbone, J.C.; Hallstrom, D.G.; Smith, V.K. Can natural experiments measure behavioral responses to environmental risks? Environ. Resour. Econ. 2006, 33, 273-297. [CrossRef]

59. Alonso, W. Location and Land Use; Harvard University Press: Cambridge, MA, USA, 2013. 